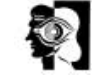

columns had been granted. In all other cases where the child or young person had been seen in the past in CAMHS, but is not currently being seen at the time of handover, referral to the adult services should be accompanied by permission from the patient and family wherever possible.

- Information from third informants should be removed from the case notes before they are handed over. Where this is not possible, permission should be sought for their disclosure from those informants.

We would be interested to receive feedback from members in relation to this policy.

Mike Shooter Registrar, Royal College of Psychiatrists, 17 Belgrave Square, London SW1X 8PG

\section{Research prize 2001}

The Research Advisory Group of the Royal College of Psychiatrists Scottish Division established a new prize in 2000, awarding $\mathrm{f} 1000$ for the best paper published in the year 2000. Papers are now being accepted for the prize next year. Papers must be published in the year 2001. Please see the rules below.

\section{Judging}

The Chairman, Secretary and one other Member of the Scottish Division Research Advisory Group, along with the Chairman and Honorary Secretary of the Scottish Division, will make up a five-member panel.

\section{Submissions}

- The submission will be a single paper published in a peer-reviewed journal in the year 2001. Submissions should be accompanied by a letter stipulating clearly the part the applicant had played in the research.

- Please submit entries to the Honorary Secretary of the Scottish Division by the end of January 2002. Judging will take place in February with the winner being informed by letter shortly afterwards.

- The winner of the research prize will be expected to present his or her paper at a meeting of the Scottish Division in 2002

- The applicant must be a member of the College and must have been working in Scotland at the time the research was carried out.

- Entries can be e-mailed to k.addie@virgin.net

\title{
obituaries
}

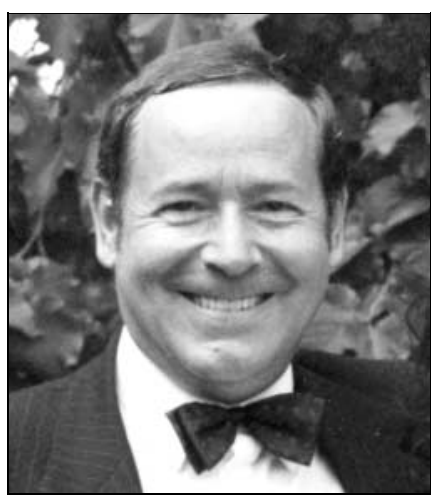

\section{Dr Leslie Stuart Cantlay}

Formerly Consultant General Psychiatrist, County Durham and Darlington Priority Services NHS Trust

Leslie Stuart Cantlay died suddenly on 5 January 2001. Leslie, who liked to be caled Les, was a proud Scotsman who was born in 1945 in Aberdeen and spent his early years there until 1952, when the family emigrated to Rhodesia where Les' father taught agriculture. After 2 years in Nyasaland, Les returned to Aberdeen at the age of 13 where he attended Aberdeen Grammar School and then Aberdeen University Medical School, where he graduated MB Ch B in 1969.

He married Sheila, an Arts student, in 1969 in King's College Chapel, Aberdeen and after his pre-registration year he worked in psychiatry at the Ross Clinic in
Aberdeen and then Kingseat Hospital in Aberdeenshire.

In 1972 Les joined the Royal Army Medical Service, was posted to Northern Ireland and in 1974 returned to psychiatry and served in West Germany, Hong Kong and the Queen Elizabeth Military Hospital in Woolwich, attaining the rank of Lieutenant Colonel in 1983. He gained the MRCPsych in 1978 and was elected to the Fellowship in 1997.

In 1988 Les joined the staff at Winterton Psychiatric Hospital and practised as a general psychiatrist in the Bishop Auckland and Crook area and moved to Darlington with the closure of Winterton Hospital in 1998

Les might well be described as a 'character'. He was, for example, meticulous and precise, particularly in his use of the English language; was a great fan of Elvis, loved motorcars and was extremely proud of his recent acquisition of a silver grey mark II 'Inspector Morse' Jaguar and collected matchbox cars and trains and implements for left-handed people.

Les was an enthusiastic traveller and a few months prior to his death spent a short holiday in China visiting Beijing, the Great Wall and the Terracotta Warriors. Les enjoyed his work as a general adult psychiatrist and particularly enjoyed teaching and training junior doctors; his knowledge of training regulations and training schemes was second to none.

Leslie L. Burton

\section{Charles B. Whittaker}

Formerly Medical Superintendent, Carstairs State Hospital

Charles B. Whittaker - Charley to his many friends - died unexpectedly in hospital in Edinburgh on 26 October 1998 at the age of 72 . He had been retired from psychiatric work for some years and had been fairly recently married (for the first time) to Georgina, a retired nursing sister, who survives him.

He studied medicine at Edinburgh University (graduated MB Ch B 1947) and specialised in psychiatry early in his career, working at the Crichton Royal Hospital in Dumfries. Later on, during the 1970s, he became a consultant psychiatrist at Gogarburn Hospital in Edinburgh and subsequently - following the disastrous events surrounding the escape of a dangerous patient from there in 1985 he was for some years the Medical Superintendent of Carstairs State Hospital.

A Unitarian and humanist and deeply conscientious man, Whittaker was interested in literature and comparative religion and worked unceasingly for reconciliation between people of different beliefs. He became particularly committed to the Council of Christians and Jews, on whose behalf he visited Israel several times.

He is much missed by everybody who had the privilege of knowing him.

Margaret J. Little 